\title{
TGFB1-Induced Anti-Apoptotic Factor 1
}

National Cancer Institute

\section{Source}

National Cancer Institute. T GFB1-Induced Anti-Apoptotic Factor 1. NCI Thesaurus. Code C101374.

TGFB1-induced anti-apoptotic factor $1(115 \mathrm{aa}, \sim 12 \mathrm{kDa})$ is encoded by the human TIAF1 gene. This protein plays a role in the modulation of apoptosis. 